\title{
PHASEOLUS ANGUCIANAE (LEGUMINOSAE: PHASEOLEAE), A NEW BEAN SPECIES FROM FILA CRUCES OF SOUTHEASTERN COSTA RICA
}

\author{
D.G. Debouck \\ International Center for Tropical Agriculture (CIAT) \\ Cali, $A$ A 6713 \\ COLOMBIA \\ d.debouck@cgiar.org
}

\author{
R. Araya-Villalobos \& N. Chaves-Barrantes \\ Estación Experimental Agrícola "Fabio Baudrit Moreno" \\ Universidad de Costa Rica (UCR) \\ San José, COSTA RICA \\ avillalo2005@hotmail.com; nfchaves@gmail.com
}

ABSTRACT

A new wild bean found in the mountainous range "Fila Cruces" of southeastern Costa Rica is described. To date, only four populations are known from different sites on the slopes of Cerro Anguciana and "Fila Cruces" where it seems to be endemic. The differences (slender curved racemes, small oval acuminate primary and pedicelar bracts, lilac inner face of standard, white wings) are presented with closely related species such as P. hygrophilus and P. oligospermus of the section Brevilegumeni to which it may belong.

\section{RESUMEN}

Se describe una nueva especie silvestre de fríjol encontrada en la Fila Cruces en el sureste de Costa Rica. Hasta la fecha se conocen sólo cuatro poblaciones de sitios distintos de las vertientes del Cerro Anguciana y de la Fila Cruces, de donde parece ser endémica. Se muestran las diferencias (tales como racimos encorvados largos y delgados, con pequeñas brácteas primarias y pedicelares ovales acuminadas, la cara interna del estandarte lila y las alas blancas) con especies cercanas tales como P. hygrophilus y P. oligospermus de la sección Brevilegumeni a la cual podría pertenecer.

KEY WordS: tropical legumes, endemism, montane forest, typification

\section{INTRODUCTION}

On August 5, 2003, in the framework of the project Flora of Costa Rica, Mary Merello of Missouri Botanical Garden sent a digital image of a bean plant to one of us (DGD) asking for identification. The label read: "Flora de Costa Rica. Fabaceae/ Pap. dup.= 4. Phaseolus. Det. [blank space]. Puntarenas. Cantón de Osa, Fila Costeña, Fila Cruces; N of headwaters of Río Piedras Blancas, W slope of Cerro Anguciana. 08 $49^{\prime} 12^{\prime \prime N}, 8^{\circ} 11^{\prime} 15^{\prime \prime} \mathrm{W}$ 950-1400 m. Vine in pasture and along trail in forest; fls. purplish. Michael Grayum 10618, B Hammel, R Aguilar E J Gómez. 8 December 1993. Instituto Nacional de Biodiversidad (INB), en colaboración con el Missouri Botanical Garden (MO)." With the floristic information available at that time for Costa Rica (Araya-Villalobos et al. 2001; Freytag \& Debouck 2002) and neighboring Central American countries (for Nicaragua: DelgadoSalinas 2001; for Panama: Lackey \& D'Arcy 1980), it was not possible to identify this specimen to the species level, while confirming it as a Phaseolus sensu stricto (Maréchal et al. 1978; Lackey 1983), and a field visit to the original site was therefore deemed necessary.

Attempts to find that bean plant on the slope of Cerro Anguciana from the southwest in December 2003 and once more in January 2004 failed because of deforestation and rough topography, respectively. Another try on December 11, 2012 from the northeast succeeded: a second population (\#3243) of this taxon was found. A third population (\#3369) was found on December 15, 2017 in the eastern part of Fila Cruces; these populations allowed the observations reported below. In the meantime, because of the need to advance the Flora of Costa Rica, Nelson Zamora in March 2007 identified this specimen Grayum 10618 and reconfirmed it in September 2008 at MO (acronyms of herbaria Thiers 2017) as Phaseolus talamancensis Debouck \& Torres-González (Tropicos 2009, 2017), an identification on which we noted a discrepancy (see below in Diagnosis). This identification seems also reflected in the latest treatment for the genus for that Central American country (Zamora 2010:675). The purpose of this paper is the description of this new taxon. 


\section{MATERIALS AND METHODS}

The following observations were made on plants studied at the original sites and then as herbarium voucher specimens at USJ using stereomicroscope and calipers. The species P. hygrophilus Debouck (specimen Debouck \& Araya 3172, as INB0004026793 and G40815 in CIAT genebank), P. oligospermus Piper (specimen Debouck et al. 3107, as CR212974 and G40762) and P. talamancensis (Debouck \& Araya 3182, as CR238742 and G40814) used in the comparisons (flower, pod, and seed, as well as the seedling of the new taxon) were plants growing freely in closed greenhouses at CIAT experimental station in Popayán, Cauca, Colombia (at 02 $31^{\prime} 02.8^{\prime \prime} \mathrm{N}$, $76^{\circ} 38^{\prime} 04.4^{\prime \prime} \mathrm{W}, 1765$ masl, on Andean inceptisol soil) from seeds collected at the original locality. Digital images also contribute to these comparisons. Because there are no genetic alterations (first generation after original collecting in the wild, closed growing environment), these plants can be considered as representative of their original conditions. Therefore, all these plants can be considered under the Botanical Code (viz. the Melbourne Code: McNeill et al. 2012) not the Cultivated Plant Code as explained by Spencer and co-workers (Spencer et al. 2007:58-59).

\section{RESULTS}

Phaseolus angucianae Debouck \& Araya, sp. nov. (Figs. 1-7). TYPe: COSTA RICA. Puntarenas: Golfito (cerca al límite con Coto Brus), distrito Guaycará, Agua Buena, en carretera lastreada hacia Río Claro a 9 km W de entronque carretera Agua Buena San Vito, GPS: 0847'07.9"N, 8302'01.3"W, 1498 msnm, 15 Dec 2017, Daniel Gabriel Debouck 3369, Rodolfo Araya Villalobos \& Néstor Chaves Barrantes (hоLоTYPE: USJ111488; IsOTYPES: BRIT476561, CR286418, GH, K, MICH, MO, NY, P).

Phaseoli hygrophili primo adspectu simile, sed caulibus volubilibus minoribus foliolisque basis truncatae oblongis minus saepe ad centrum variegatis racemisque gracilibus cum 5-9 bracteis primaris rotundatis $2.5 \mathrm{~mm}$ angustioribus et vexillo $7 \mathrm{~mm}$ lato angustiore purpureo lilacino scilicet auricula sinistra. Crescit in sylvis pluvialis montis Angucianae ad $1400 \mathrm{~m}$ supra mare rarus.

Plant 70-150-250 cm high, climbing indeterminate vine, 3-4 axillary shoots branching from lower nodes, 4-8 lateral inflorescences. Seedling 6-8 cm high (Figs. 1a, 6a), from hypogeal germination, epicotyl terete glabrous $10 \mathrm{~mm}$ dark purple, eophylls opposite triangular slightly cordate at base acuminate petiolate glabrous green, the blade $14 \times 12 \mathrm{~mm}$, the petiole terete, green, $9 \mathrm{~mm}$ long, stipules and stipels absent, pulvini green. First true leaf trifoliolate green glabrous, not variegated nor lobed, terminal leaflet symmetrical lanceolate $24 \times$ $10 \mathrm{~mm}$, lateral leaflets asymmetrical lanceolate $14 \times 9 \mathrm{~mm}$, petiole $10 \mathrm{~mm}$, rachis $2 \mathrm{~mm}$, stipules unconspicuous. Root not seen but suspected to be pluriannual (see ecology below). Stem 70-250 cm vine, diameter 2-2.5-3 mm (Fig. 1b), internodes terete striate 85-135 mm long, scandens in lower parts to twining in upper parts of the plant, green to purplish (when exposed to solar radiation), sparsely puberulent with short yellowish-brown hairs and minute uncinate hairs. Stipules (2, flanking the insertion of proximal pulvinus of petiole) basifix, triangular pointed $5 \times 3.5 \mathrm{~mm}, 8-10$ veined, green to purplish, glabrous with a few short whitish hairs on the tip. Leaves trifoliolate with stipels, petiole, rachis, and pulvini (Fig. 1b) in distichous sequence, dark green above, silvery green beneath, lamina and veins sparsely covered with whitish short straight and minute uncinate hairs. Terminal leaflet oblong acuminate (acumen $7 \mathrm{~mm}$ long) to caudate, symmetrical truncate at base (61) $78 \times$ (27) $33 \mathrm{~mm}$. Lateral leaflets asymmetric acuminate (56) $65 \times$ (32) $37 \mathrm{~mm}$ sometimes wider than terminal leaflet. Variegation often present along main veins of both leaflets but discontinuous from base to tip. Stipels narrowly lanceolate $2.5-3 \mathrm{~mm}$ long $\times 1 \mathrm{~mm}$ wide, 3-4 well marked veins, glabrous. Petiole 33-53 mm long, diameter $1.5 \mathrm{~mm}$ at base, rachis $13-17 \mathrm{~mm}$ long, green to purplish, canaliculate, finely striate with short straight whitish and minute uncinate hairs sparsely distributed. Pulvini terete, proximal $4 \mathrm{~mm}$ (distal at axils of leaflets $3 \mathrm{~mm}$ ) long, green, densely covered with short light brown straight and minute uncinate hairs, active. Inflorescence a slender loosely curved pseudo raceme (raceme of racemes) pointing out of the foliage with rachis longer than peduncle and 5-9 primary bracts (Figs. 1b, 2b) and 5-9 floral nodes, appearing first as an oblong group of light green floral buds, the terminal part drying up if pods formed at first node. Peduncle terete, curved, 53-93 mm long, diameter $1.5 \mathrm{~mm}$ at base, rachis terete, curved, 80-160 mm long, both finely striate, green to purplish red, sparsely covered with minute uncinate hairs. Primary bracts oval, acuminate, convex, tip reflexed, $2.5 \times 2.5 \mathrm{~mm}$, hyaline, glabrous, green, 6-8 veins (Fig. 1c), persistent till after anthesis. Pedicel terete, green reddish to dark purple, $11-15 \mathrm{~mm}$ long (to $20 \mathrm{~mm}$ long with maturing pod), sparsely 

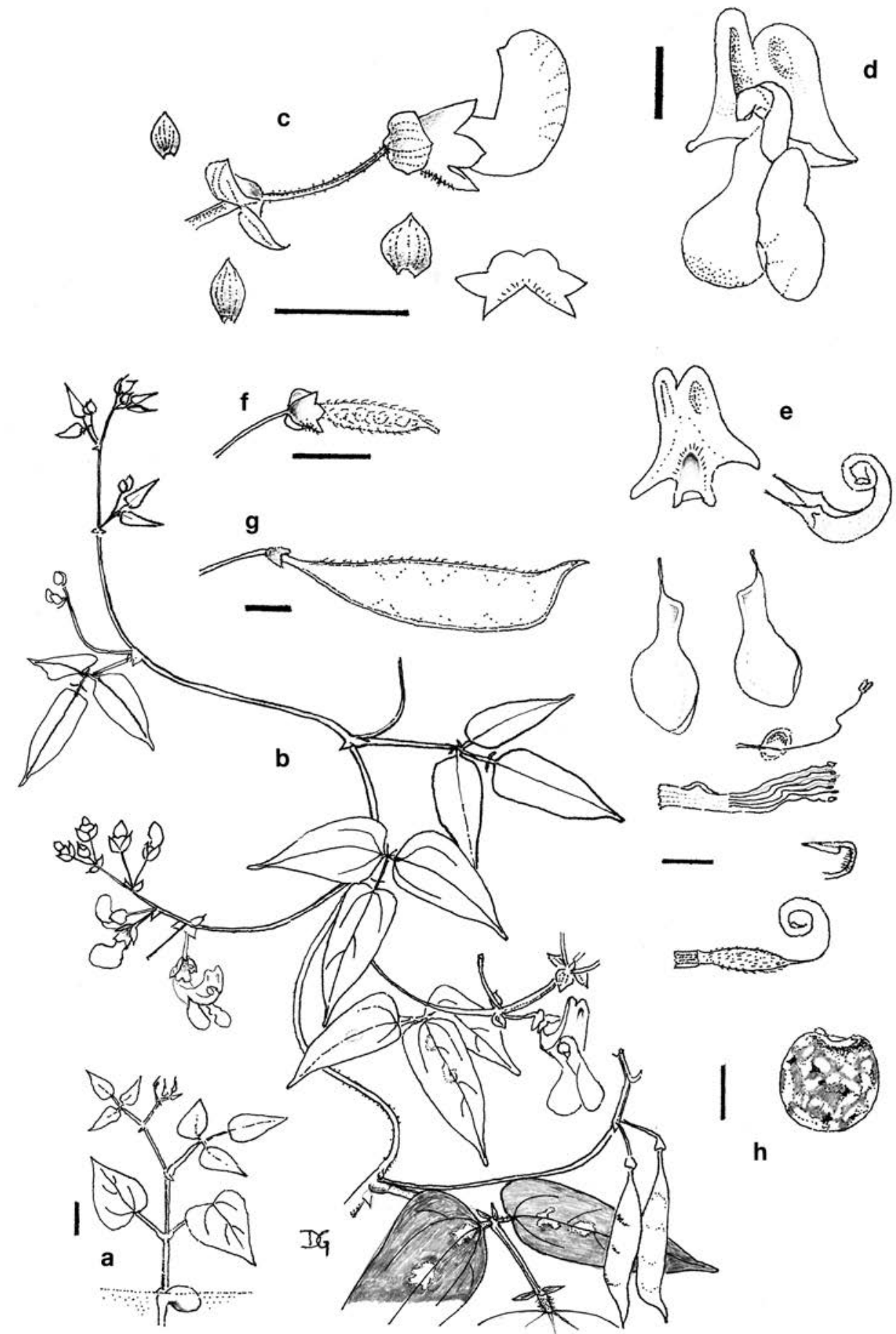

FIG. 1. Phaseolus angucianae: seedling, stem, leaves, racemes, flower, seed (illustration by first author). a: seedling. b: flowering and fruiting stem, with curved racemes. c: floral bud and calyx (below right), with primary bract (upper left), pedicelar bract (below left) and bracteole (below right). d: flower (facing observer). e: floral parts: banner petal (left), keel (right), wings, vexillar stamen, staminal tube, ovary and style; stigma (right). f: young pod. g: developed pod. h: mature seed (scale bar: $10 \mathrm{~mm}$, for all except for flower and floral parts $5 \mathrm{~mm}$ ). 
covered with minute uncinate hairs, sometimes still persistent after the flower has dropped. Pedicelar bract ( 2 , flanking the primary bract) inserted just at the base of each pedicel, oval, acuminate, tip reflexed, $4 \mathrm{~mm}$ long, glabrous, hyaline, purplish, 8-10 veins, still persistent after anthesis. Flower papilionaceous asymmetrical (Figs. 1d, 3a), usually two inserted on a very short axis at each primary bract and differing by one day in anthesis sequence. Bracteoles 2, inserted on greenish floral receptacle, rounded, shortly acuminate, 3-4 mm long, 3/4 to calyx tube, 5-7 finely veined, glabrous, purplish turning green at tip, sometimes persistent till half development of pod. Calyx $6 \mathrm{~mm}$ long $6 \mathrm{~mm}$ high $3 \mathrm{~mm}$ wide, tube $4 \mathrm{~mm}$ long, upper 2 lobes united, forming a slightly emarginate lip, the free part of which is $1 \mathrm{~mm}$ long, 3 lower lobes triangular, rounded and pointed, 2-3 $\mathrm{mm}$ long, with just a few straight, short, brown hairs on central lobe and minute uncinate hairs, red-purplish at base, greenish towards lobe tips. Corolla white to pale lilac, fading yellow to light orange. Standard external face glabrous, $4 \mathrm{~mm}$ to flexure, $6 \mathrm{~mm}$ to tip (Fig. le), lower part greenish turning white, upper part whitish turning lilac, claw $2 \mathrm{~mm}$ long, internal thickening but no callosities at flexure, internal face asymmetrical, $6 \times$ $7 \mathrm{~mm}$, markedly cupped with a central fold ending at the tip into a $2 \mathrm{~mm}$ deep sinus, glabrous, white at base then purple lilac throughout and more intense on internal auricles namely the left one (facing observer) which is folded forward and more developed as compared to the right one, right auricle bending backward almost touching the upper lip of calyx. Wings obovate, subequal, truncate at base, margins smooth, slightly curved downward, spreading at right angle in relation to standard, glabrous, the right wing (facing observer) 16-18 $\times$ $10 \mathrm{~mm}$, often superseding internally on the left one, claws linear, $5 \mathrm{~mm}$, spur angled adhering to the keel, white to very pale lilac, fading cadmium yellow the day after anthesis. Keel tubular, asymmetrical, ending into two close counterclockwise (facing observer and parallel to observer's face) almost complete coils, white but markedly greenish gold on the last coil, claws linear, $4 \mathrm{~mm}$, two petals almost fused all along, ca. $16 \mathrm{~mm}$ long, $3 \mathrm{~mm}$ wide to pockets $1.5 \mathrm{~mm}$ high, adhering to the wings, tube $6 \mathrm{~mm}$ to the coils, diameter of last coil $2.5 \mathrm{~mm}$. Stamens diadelphous $(9+1)$. Staminal tube white, delicately veined, glabrous, $2.5 \mathrm{~mm}$ to spur then $3.5 \mathrm{~mm}$ to filaments, $12 \mathrm{~mm}$ long. Vexillar stamen white, $18 \mathrm{~mm}$ long, claw terete, $2 \mathrm{~mm}$ with rounded cupped knob 1.5 $\mathrm{mm}$ diameter. Anthers brown, rectangular rounded, $0.5 \mathrm{~mm}$, dithecous, dorsifixed, longitudinally dehiscent. Ovary laterally compressed, $6 \times 1.5 \mathrm{~mm}$, greenish white, densely covered with ferruginous hairs, inserted on a $2 \mathrm{~mm}$ long finely veined whitish floral disk, basal nectary not developed, 4-6 ovules. Style white, terete, 12 $\mathrm{mm}$, coiled with 2 close coils at tip, glabrous but with a dense internal brush below the terminal stigma; stigma conical, $1.5 \mathrm{~mm}$, not extending beyond the tip of the style; the terminal part of style caducous when the pod is formed. Pod laterally compressed, when young $13 \times 4 \mathrm{~mm}$ densely covered with ferruginous dark brown hairs (Fig. 1f). Developing pod with sigmoid dorsal suture towards pod beak (Fig. 6b). Mature pod (3)-4-(5) seeded, sparsely covered with dark brown hairs (Figs lg, 4a, 6c), green, maturing tan to dark brown, flattened, 53-68 $\mathrm{mm}$ long, 10-15 mm wide. Base of pod stipitate, 4-5 mm long, terminal part prow shaped. Beak short, 2-4 mm stout. Sutures delicately defined, the dorsal one finely marked, ciliate with dark brown hairs. Seed laterally compressed, rounded, slightly squarish, $16 \times 13 \times 4 \mathrm{~mm}$ (Figs. 1h, 5a), dark tan to brown with cream and black speckles, dense black speckling around the whitish hilum, shiny, 100-seed weight $=6.51(6.02-7.10) \mathrm{g}$.

Paratypes: Costa Rica. Puntarenas: Cantón de Osa, Fila Costeña, Fila Cruces; N of headwaters of Río Piedras Blancas, W slope of Cerro Anguciana. 0849'12"N, 83¹1'15"W, 950-1400 m, 8 Dec 1993, Michael Grayum 10618, Barry Hammel, Reinaldo Aguilar E Jesús Gómez (INB, MO6103483 and MO6103484). Puntarenas: Golfito, ladera W del Cerro Anguciana, 8 km SW de Paraíso, GPS: 0848'34.9"W, 8309'38.8"W, 1539 msnm, 15 Dec 2017, Daniel Gabriel Debouck 3243, Rodolfo Araya Villalobos \& Néstor Chaves Barrantes (K, MO, USJ111487) (Fig. 2b). Puntarenas: Coto Brus (cerca al límite con Golfito), distrito Limoncito, en carretera lastreada a Río Claro a $14.2 \mathrm{~km}$ W de entronque carretera Agua Buena-San Vito, en Km 11.5 desvío a la derecha, GPS: 0847'00.0"N, 8303'13.4"W, 1497 msnm, 8 Feb 2018, Néstor Chaves Barrantes $0006 \&$ Rodolfo Araya Villalobos (BRIT, CR286428, GH, K, MO, USJ111528).

Diagnosis and key to species.-According to the Tropicos database (Tropicos 2017), the specimen Grayum 10618 has been identified as P. talamancensis. There is also a specimen of the same collection by Michael Grayum and co-workers kept at INB and identified as P. talamancensis by Nelson Zamora on March 6, 2007, and seen by one of us (DGD) on March 13, 2013. Figs. 3 a,b and 4 a,b and Table 1 indicate that this specimen does not belong to this taxon. 


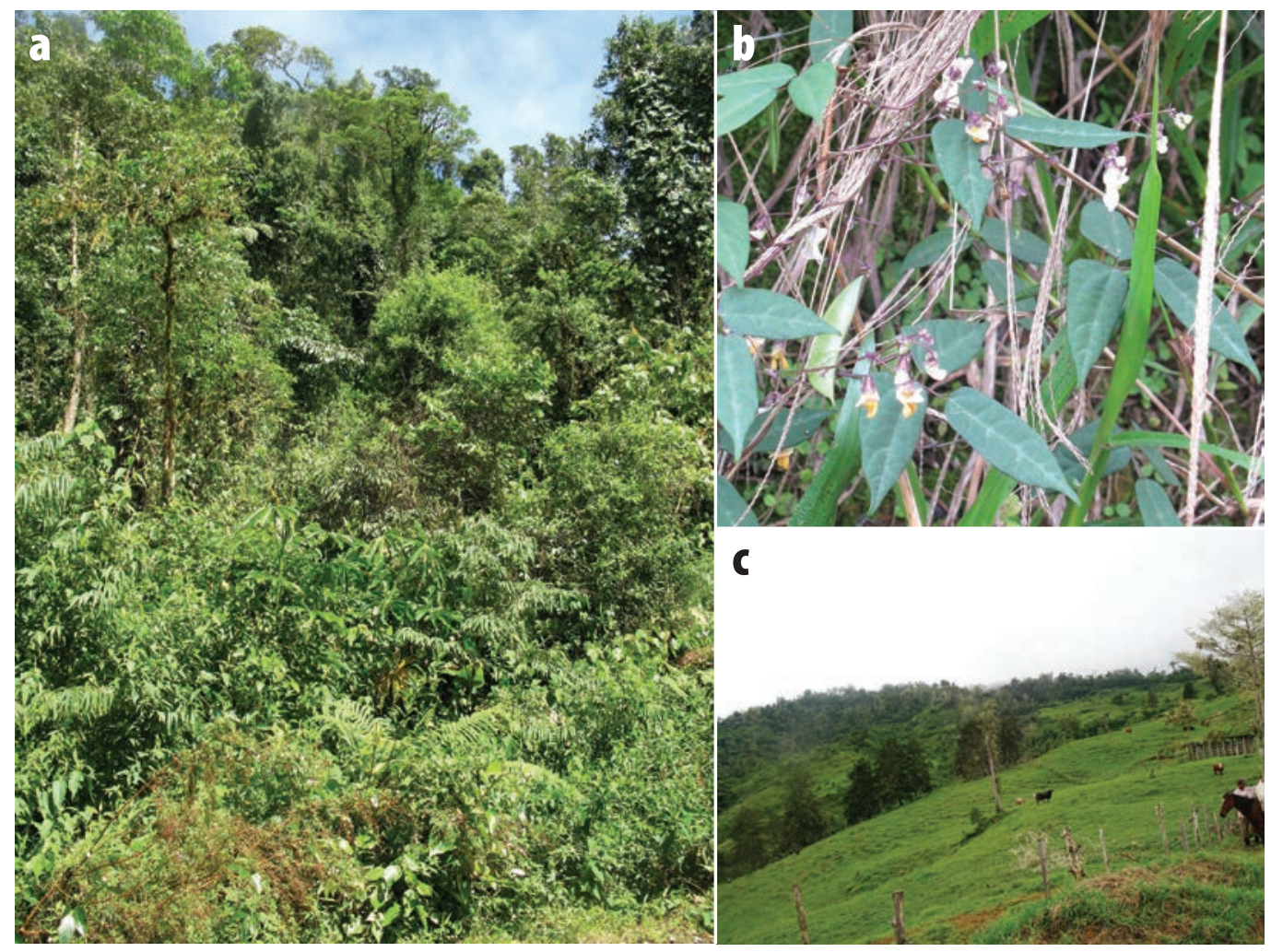

FIG. 2. Phaseolus angucianae: 2 a: habitat of population \#3369. 2b: blooming racemes of population \#3243 among old panicles of Paspalum saccharoides. 2c: deforestation of northern slope of Fila Cruces at 1450 masl about $6.5 \mathrm{~km}$ W of El Paraíso.

Among all species of Phaseolus thriving wild in Costa Rica (Table 2, from which P. acutifolius Asa Gray has been excluded since it exists as cultigen: Zamora 2010), the closest species which P. angucianae could be compared with seem to be P. oligospermus because of the size of the plant, growth habit, and leaflet characteristics (size, shape, base, acumen), and P. hygrophilus Debouck because of the flower traits, given the descriptions provided by Piper (1926) and Salcedo-Castaño and co-workers (2011), respectively. The differences in raceme and flower characteristics (Tables 3 and 4; Fig. 3a-d) are believed to be strong enough to warrant the species status.

While leaflets of $P$. angucianae and $P$. oligospermus share similarities in size, acumen, and color, external broad or narrow round lobes on lateral leaflets have not been seen in the former taxon. Racemes of $P$. angucianae are less vigorous and shorter with a marked curvature compared to those of $P$. oligospermus and primary bracts are different in size and shape (Table 3). Pedicelar bracts and bracteoles differ in size and shape, too; venation of these bracts is noteworthy in P. angucianae. Inner standard is pale lilac with a greenish cast and wings are lilac purple in P. oligospermus, while intense purplish lilac and very pale lilac to full white, respectively, in P. angucianae (Fig. 3a,d).

In addition, $P$. angucianae thrives in a lower montane rain forest (along a terminology introduced by TosiOlin in 1969) (with little or no human activity) while P. oligospermus grows in premontane moist forest (separated from the former by 1500 to $2000 \mathrm{~mm}$ rainfall per year and a dry season twice that long: Bolaños-Montero \& Watson-Cépedes 1993 and Herrera-Soto \& Gómez-Pignataro 1993, respectively) and can tolerate some habitat modifications by humans. In this regard, it is worth reminding that the range of $P$. oligospermus extends 


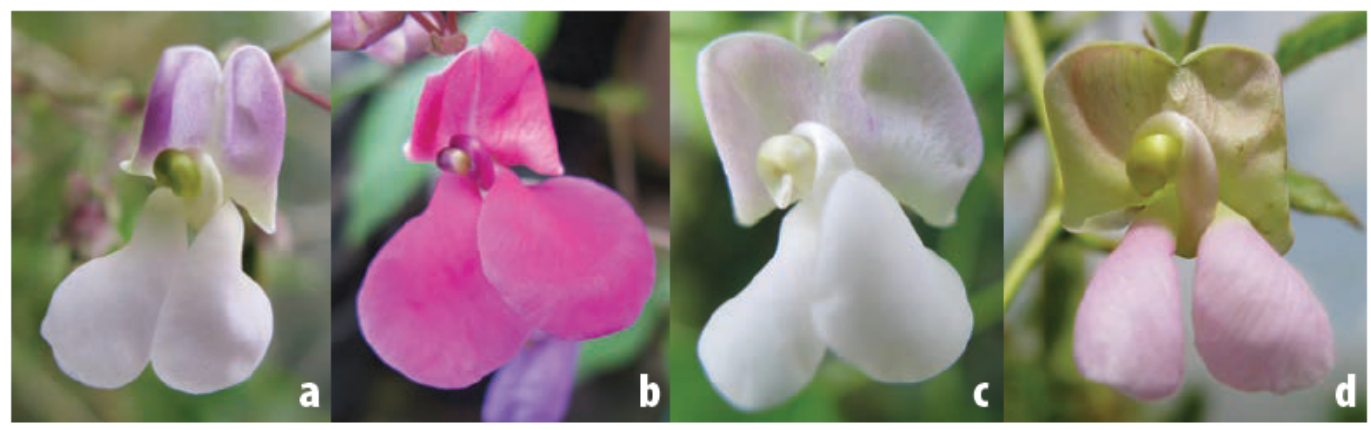

FiG. 3. Close-ups of flowers, the standard petal facing the observer. 3a: P. angucianae (Deboucket al. 3369). 3b: P.talamancensis (Debouck \& Araya 3182 ). 3c: P. hygrophilus (Debouck \& Araya 3172). 3d: P. oligospermus (Debouck et al. 3107).

TABLE 1. Comparison between P. angucianae and P. talamancensis for key diagnostic traits.

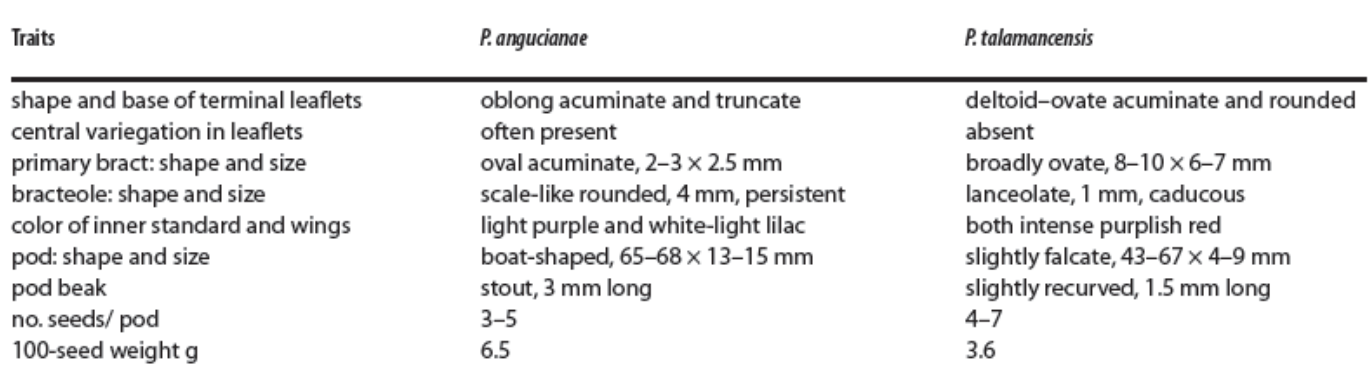

Tabie 2. Quick overview of wild Phaseolus species known to be present in Costa Rica (by alphabetic order of sections as currently defined: Freytag \& Debouck 2002).

\section{Bracteati Freytag}

1. P. talamancensis Debouck \& Torres

Brevilegumeni Freytag

2. P. angucianae Debouck \& Araya

3. P. hygrophilus Debouck

4. P. oligospermus Piper

5. P. tuerckheimii Donnell-Smith

\section{Falcati Freytag}

6. P. leptostachyus Benth.

\section{Paniculati Freytag}

7. P. lunatus L. (wild)

\section{Phaseoli DC}

8. P. costaricensis Freytag \& Debouck

\section{P. dumosus Macfady. (weed)}

10. P. vulgaris L. (wild)

\section{Xanthotricha Delgado}

11. P. xanthotrichus Piper

12. P. microcarpus Mart.
Debouck et al. 2130 (CR), Davidse \& Herrera 29127 (MO), E Alfaro 2508 (INB), G Herrera 3590 (MO), JF Morales 8861 (K)

Grayum et al. 10618 (MO), Debouck et al. 3243, 3369 (USJ), Chaves \& Araya 0006 (USJ) Debouck \& Araya 3172 (INB), Debouck \& Araya 3173 (USJ)

Oersted 30 (K), Debouck \& Araya 2091 (BR), Debouck et al. 3107 (CR)

W Burger 4028 (F), Debouck et al. 2125 (MICH), JL Luteyn 4541 (DUKE)

AM Brenes 4568 (F), ER Heithaus 438 (MO), Debouck et al. 3306 (CR), AO Tonduz 7200 (G)

A Carvajal 311 (MEXU), A Smith 2436 (UC), PC Standley 35853 (US), N Garwood et al. 817 (BM), H Pittier 4992 (G)

MF Barrus 318 (USJ), Deboucket al. 2135 (US), PH Allen 555 (GH), AF Skutch 2990 (GH), AOTonduz 1475 (M)

RL Wilbur 28858 (DUKE), EAlfaro 3762 (INB), F Quesada et al. 1172 (K)

Debouck et al. 3126 (INB), Debouck et al. 2111 (US), CO Morales 621 (USJ)

Debouck \& Araya 2105 (US), P Biolley 8999 (BR), B Hammel 23864 (INB)

B Hammel 24516 (INB), Debouck et al. 3284 (CR)

Sources: Debouck 2017a, Salcedo-Castańo et al. 2011, Zamora 2010, and present results. 
TABLE 3. Comparison between $P$. angucianae and $P$. oligospermus for key diagnostic traits.

\begin{tabular}{lll}
\hline Traits & P. angucianae & P. oligospermus \\
\hline shape and base of terminal leaflets & oblong acuminate and truncate & lanceolate acuminate and truncate \\
central variegation in leaflets & often present, discontinuous & often present, continuous \\
primary bract: shape and size & oval acuminate $2.5 \times 2.5 \mathrm{~mm}$ & triangular lanceolate $5-6 \times 2 \mathrm{~mm}$ \\
no. of primary bracts & $5-9$ & $5-16$ \\
raceme vigor, length & slender curved, $155-220 \mathrm{~mm}$ & stout erect, $100-390 \mathrm{~mm}$ \\
pedicelar bracts: shape and size & oval acuminate $4 \mathrm{~mm}$ long & lanceolate $3 \mathrm{~mm}$ long \\
bracteole: shape and length & scale-like rounded $4 \mathrm{~mm}$ & lanceolate $2 \mathrm{~mm}$ \\
color of inner standard and wings & purple and pale lilac & pale lilac-greenish and lilac-purple \\
pod length and width & $65-68 \times 13-15 \mathrm{~mm}$ & $40-60 \times 11-12 \mathrm{~mm}$ \\
pod beak: shape and size & stout, $2 \mathrm{~mm}$ long & stout, then recurved, $5 \mathrm{~mm}$ long \\
no. seeds per pod & $3-5$ & $2-4$ \\
seed shape; 100 -seed weight $\mathrm{g}$ & rounded-squarish; 6.5 & oval; 5.9 \\
Life zones and biotic units 1,2 & bp-MB; 23 & bh-P; 31 \\
\hline
\end{tabular}

\footnotetext{
${ }_{1}^{1}$ Bolaños-Montero \& Watson-Cépedes 1993. bp-MB= bosque pluvial Montano Bajo. bh-P= bosque húmedo Premontano.

${ }^{2}$ Herrera-Soto \& Gómez-Pignataro 1993.
}

TABLE 4. Comparison between P. angucianae and P. hygrophilus for key diagnostic traits.

\begin{tabular}{lll}
\hline Traits & P. angucianae & P. hygrophilus \\
\hline plant height & $1-2.5 \mathrm{~m}$ & $2.5-5 \mathrm{~m}$ \\
terminal leaflet & oblong acuminate $63 \times 22 \mathrm{~mm}$ & lanceolate apiculate $77 \times 50 \mathrm{~mm}$ \\
terminal leaflet base & truncate & rounded \\
central variegation & often present, discontinuous & always present, continuous \\
raceme length & $155-220 \mathrm{~mm}$ & $110-170 \mathrm{~mm}$ \\
primary bract & oval acuminate $2.5 \times 2.5 \mathrm{~mm}$ & rounded cupped $5 \times 5 \mathrm{~mm}$ \\
no. ary bracts $_{\text {pedicelar bracts }}$ & $5-9$ & 9 -18 \\
bracteole & oval acuminate $4 \times 4 \mathrm{~mm}$ & rounded cupped $2.5 \times 2 \mathrm{~mm}$ \\
calyx lobes & scale-like rounded $3-4 \mathrm{~mm}$ & rounded cordiform $3.5 \mathrm{~mm}$ \\
flower color & broadly triangular $1.5 \times 2 \mathrm{~mm}$ & prominent rounded apiculate $4 \times 4 \mathrm{~mm}$ \\
standard width & standard purple, wings pale lilac & standard pinkish white, wings white \\
developing pod dorsal suture & 9 mm & 14 mm \\
pod & sigmoid & straight \\
seed shape and 100-seed weight g & boat-shaped stipitate $55 \times 12 \mathrm{~mm}$ & boat-shaped stipitate $62 \times 12 \mathrm{~mm}$ \\
Life zones and biotic units ${ }^{1,2}$ & rounded squarish; 6.5 & circular lenticular; 6.4 \\
\hline
\end{tabular}

\footnotetext{
${ }_{1}^{1}$ Bolaños-Montero \& Watson-Cépedes 1993. bp-MB= bosque pluvial Montano Bajo (lower montane rain forest). bp-P= bosque pluvial Premontano (premontane rain forest).

${ }^{2}$ Herrera-Soto \& Gómez-Pignataro 1993.
}

from Costa Rica into Chiapas, Mexico through Nicaragua, Honduras, and Guatemala (Freytag \& Debouck 2002).

Main differences between $P$. angucianae and P. hygrophilus are reported in Table 4. From our observations in the field in December 2017, P. hygrophilus, if the main stem is not destroyed, can be a tall liana more than 5

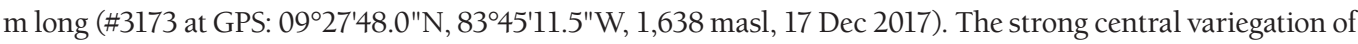
all leaflets, including on eophylls, is an outstanding feature of $P$. hygrophilus, less so in $P$. angucianae. The terminal leaflets have apices almost caudate in $P$. angucianae, less so in $P$. hygrophilus. The slender racemes of $P$. angucianae contrast with the more vigorous ones of $P$. hygrophilus, possibly because of the higher number of floral insertions. The primary and pedicelar bracts are contrasting between both taxa, almost showing reverse sizes (the relative large size of pedicelar bracts is uncommon in the genus). The standard is narrower and with a left auricle more developed in P. angucianae as compared to P. hygrophilus; the differences in standard color and second coil of keel can be seen in Fig. 3a,c. In developing pods, the dorsal suture has a noteworthy sigmoid curvature in P. angucianae, while it is almost linear in P. hygrophilus (Fig. 4a,c). 
There is not much difference in life zones of these taxa, both have total rainfall higher than $3,200 \mathrm{~mm} /$ year (Herrera 1985; IMN 1985, 2005) and frequent mists. For P. hygrophilus, our field notes indicate a tall (30 m or higher) almost evergreen two-story forest, slightly smaller in the case of $P$. angucianae, in agreement with observations made by Sawyer \& Lindsey (1971) and Holdridge and co-workers (1971). In these rain forests, the dense canopy obliges the seedlings to establish themselves in the first months with late entry into flowering. As is the case for P. hygrophilus (Salcedo-Castaño et al. 2011:Fig. 2c), we suspect that P. angucianae has some sort of pluriannual root system.

The aforementioned differences between the Phaseolus species growing in the wild in Costa Rica (Table 2) can also be summarized in the following key.

1. Plants once in flowering or bearing pods less than $2.5 \mathrm{~m}$ high.

2. Pods one-seeded diamond shaped, flower small, less than $1 \mathrm{~cm}$ long

2. Pods with several seeds, flower medium-sized, bigger than $1 \mathrm{~cm}$ long.

3. Corolla light to dark violet; keel with larger basal coil and then two close terminal coils

3. Corolla not violet; keel with 1.5 terminal coil.

4. Primary bracts foliaceous broadly ovate intense red-purple multi-nerved $9 \times 9 \mathrm{~mm}$

4. Primary bracts not foliaceous ovate to lanceolate less than $6 \mathrm{~mm}$ long.

5. Stems usually sprawling on ground, stipules ovate to rhombic, extended, 10-nerved $6 \times 5 \mathrm{~mm}$ 5. Stems usually climbing, stipules triangular 8-veined $5 \times 3.5 \mathrm{~mm}$
1. Plants once in flowering or bearing pods higher than $2.5 \mathrm{~m}$. P. microcarpus P. xanthotrichus P. talamancensis

6. Pods somewhat cylindrical slightly curved usually 5-7-seeded, pod beak curved 3-6 mm P. leptostachyus P. angucianae

6. Pods different.

7. Flowers small $15 \mathrm{~mm}$ long, wings spatulate lilac-purple, external face of standard green with a few short hairs on top P. vulgaris

7. Flowers different and bigger.

8. Lateral leaflets often with external basal lobe, inner face of standard with a greenish cast contrasting with lilacpurple wings

8. Lateral leaflets not lobed.

9. Lateral and terminal leaflets with variegation along central veins

9. Lateral and terminal leaflets without variegation.

10. Lateral and terminal leaflets densely covered by short ferruginous hairs, pods 2-3-seeded, pod beak slightly curved $4-5 \mathrm{~mm}$

10. Indumentum of lateral and terminal leaflets different.

11. Wings and inner face of standard crimson or brilliant fuschia, primary bracts lanceolate 5-10 mm, bracteoles elongate-acuminate $8 \times 4 \mathrm{~mm}$, pods slightly curved $10 \times 1.4 \mathrm{~cm}$

11. Wings and inner face of standard white, primary bracts narrowly lanceolate $6-8 \mathrm{~mm}$, bracteoles almost linear $8 \times 1.5 \mathrm{~mm}$, pods straight $7 \times 1.2 \mathrm{~cm}$

P. Iunatus P. oligospermus P. hygrophilus P. tuerckheimii P. costaricensis P. dumosus

Etymology.-The epithet "angucianae" was chosen to unequivocally link with the dominant peak, Cerro Anguciana, in the mountain range "Fila Costeña Sur" that includes "Fila Cruces" where this species seems to be endemic because ot its altitude requirements. Indeed, during the study of 85 Herbaria since 1978 to date (Debouck 2017b), we identified only four populations of this taxon (Grayum et al. 10618, Debouck et al. 3243, Debouck et al. 3369, and Chaves \& Araya 0006) from three different slopes of the same mountain range. In February 2018-when trying to find again the population disclosed by Grayum and collaborators-we could not find any Phaseolus population at the coordinates indicated on the label for the lower altitude. We deduce that this population was found at 1400 masl and higher up on the mountain of Fila Cruces.

Ecology and geographic distribution.-The records gathered so far for P. angucianae indicate a distribution apparently restricted to the "bosque tropical lluvioso de bajura" (Gómez-Pignataro 1986) or the "bosque pluvial Montano Bajo" (bp-MB = Bolaños-Montero \& Watson-Cépedes 1993) of Fila Cruces that includes small patches of a lower montane rain forest above 1400 masl (Fig. 2a, 2c; Fig. 7). This bean liana is not a botanical accident (as a seed falling from a pocket and germinating along a trail) but part of the understory of such a forest where mosses and epiphytic bromeliads are abundant on tree trunks and branches. Another indicator about original ecology are the pulvini becoming active on sunny days with clear skies in order to reduce the amount of heat in the lamina. Several tall vines (Sechium, Monstera, Philodendron) are hanging from old trees of 20-25 m high. Cecropia, Heliconia, Monochaetum floribundum, and other Melastomataceae, Araceae, 


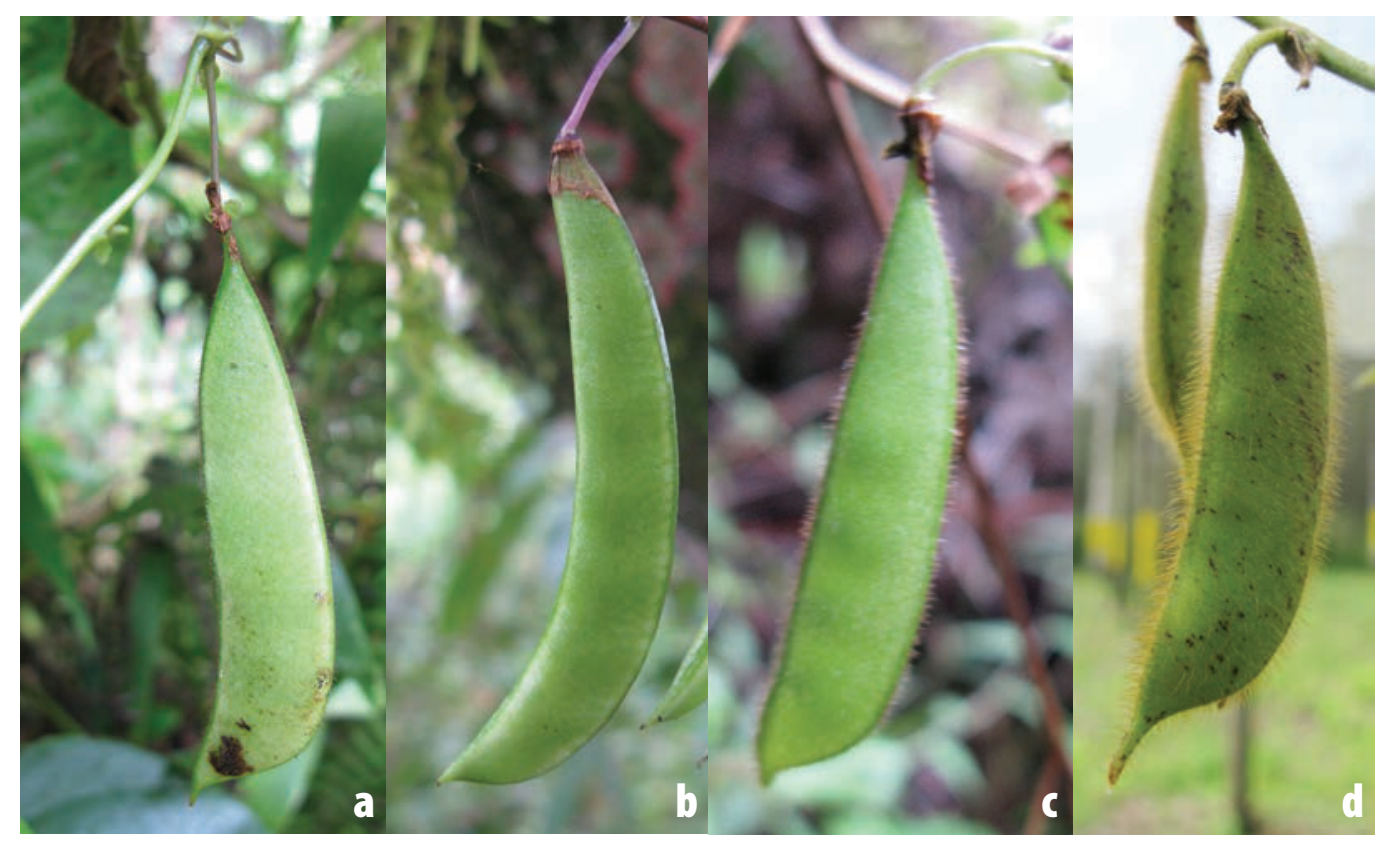

FIG. 4. Close-ups of pods. 4a: P. angucianae (Debouck et al. 3369). 4b: P. talamancensis. 4c: P. hygrophilus. 4d: P. oligospermus (all other materials as in Fig. 3).

Acanthaceae, Begonia, and Paspalum saccharoides (along trail) are part of the understory. Both tree (e.g., Cyathea) and ground (e.g. Polypodium) ferns were seen. This bean plant was found at flowering-pod filling stage in December, in a rain forest with frequent mists where the dry season lasts approximately two months (February-March according to a local informant above Paraíso). That relatively short dry season is also the one reported by the map of biotic units (Herrera-Soto \& Gómez-Pignataro 1993): unit 23 with 1-2 dry months. The upper watershed of Río Claro, where population \#0006 was found, has a dry season of 35 days in FebruaryMarch (Pérez-Rubio \& Mende 2018). Seed dispersal—for that kind of bean with this pod width, possible only if there is a dry season-occurs in the period late January-early March.

Here follows a final note about population \#3243 that we found twice, five years apart. The first collection by DG Debouck, R Araya-Villalobos, \& Karolina Martínez-Umaña (kept at INB as INB0004349263) had GPS coordinates: $08^{\circ} 48^{\prime} 34.8^{\prime \prime} \mathrm{N}, 8^{\circ} 09^{\prime} 38.7^{\prime \prime} \mathrm{W}, 1540$ masl, and was found on $11 \mathrm{Dec} 2012$. The second collection had GPS coordinates: 848'34.9"N, 8309'38.8"W, 1539 masl, and was found on 15 Dec 2017.

\section{DISCUSSION}

First, the wild bean described above is a Phaseolus sensu stricto species because it shares all distinctive characteristics of the species belonging to the genus as currently understood (Maréchal et al. 1978; Lackey 1983; Delgado-Salinas 1985; Delgado-Salinas et al. 2011), namely trifoliolate leaves with basifix stipules and stipels, minute uncinate hairs on vegetative and reproductive axes, primary bracts of raceme persistent till anthesis, pedicels longer than calyx, and absence of pedicelar nectaries.

The name of this bean plant is the second point. Consider the other Phaseolus species currently reported for Costa Rica (Zamora 2010, and Table 2), morphologically and/ or ecologically close. In the last comprehensive treatment of the genus for this country, Zamora (op.cit., p. 675) makes, under P. talamancensis, a specific reference to "S Fila Costeña (Cerro Anguciana)" without citing any specimen. We suspect the plant in reference is the one collected by Grayum et al. 10618 and reported under that identification in the Tropicos database (Tropicos 2017). The differences reported in Table 1 and in Figs. 3 and 4 clearly indicate that specimens of 


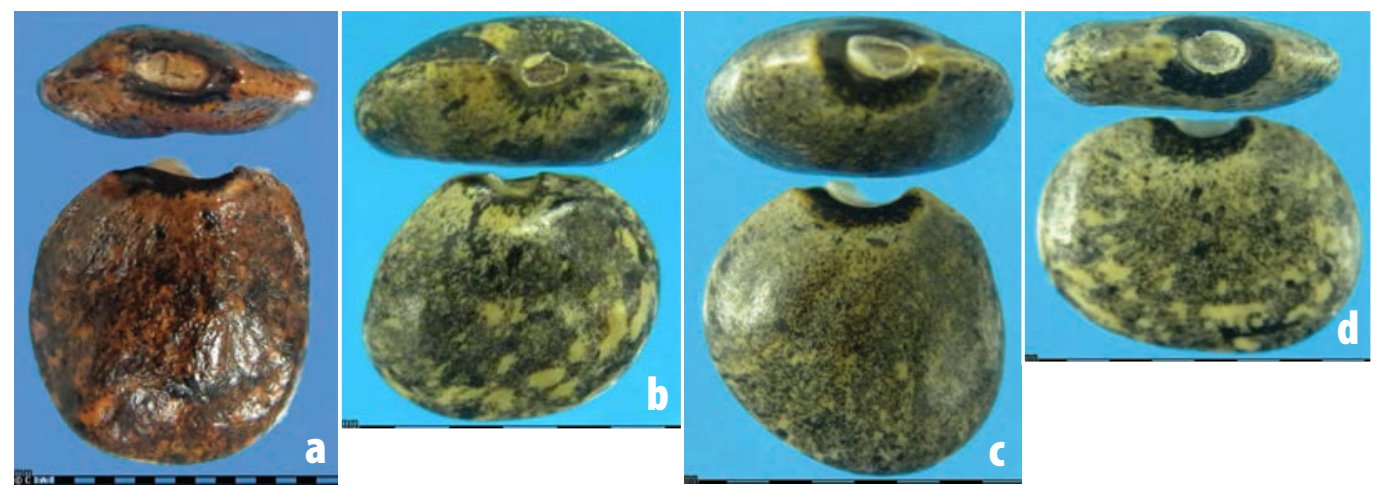

FIG. 5. Close-up of seeds (scale bar in mm). 5a: P. angucianae (Debouck et al. 3243). 5b: P. talamancensis. 5c: P. hygrophilus. $5 \mathrm{~d}$ : P. oligospermus (all other materials as in Fig. 3).

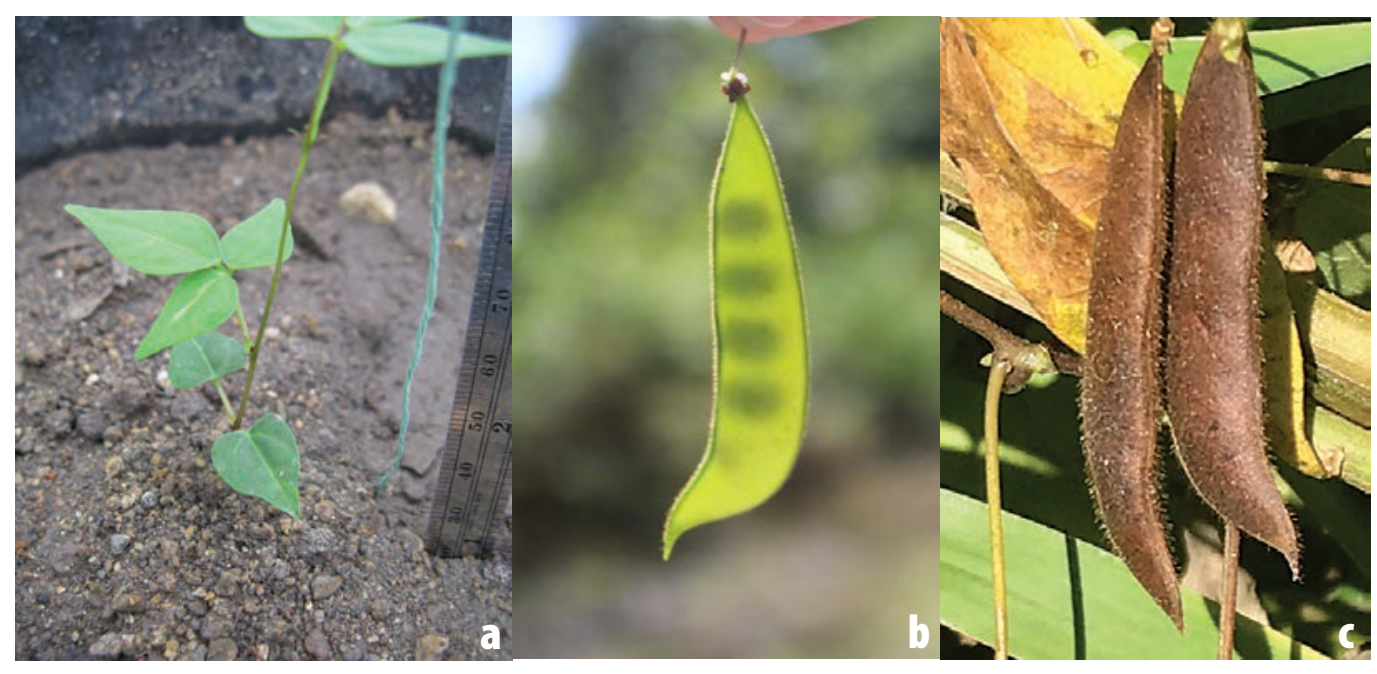

Fig. 6. Additional plant parts of P. angucianae. 6a: seedling (\#3243). 6b: green developing pod (\#3369). 6c: dry pods just before seed dispersal (\#3369).

populations \#3369, \#3243 and Grayum 10618 cannot be named as P. talamancensis (as described by TorresGonzález et al. 2001). The other white-winged beans growing freely in natural habitats in Costa Rica are $P$. dumosus Macfadyen, P. tuerckheimii Donnell-Smith, and P. hygrophilus. Specimen \#3369 is not a P. dumosus because the latter has broad ovate leaflets (usually more than $10 \times 10 \mathrm{~cm}$ ) not lanceolate truncate, leaflet without any variegation, stout multi-flowered panicles (usually with more than 12 secondary racemes), long narrow elliptical bracts and bracteoles, and relatively large golden yellow seeds (100-seed weight $=53 \mathrm{~g}$, for G36329 from the area of Dota, province of San José in Costa Rica). Mentioning P. tuerckheimii may come as a surprise to the reader, but the population Debouck et al. 2131 (specimens kept at BR, COL, CR, K, MICH, SI, UC, US and USJ) collected above San Isidro El General in January 1987 had a few individuals with white flowers. This species is a much taller ( $6 \mathrm{~m}$ and more) liana with heavily pubescent long acuminate leaflets and long racemes with 15-30 linear-lanceolate primary bracts. White flowered (winged) variants in otherwise colored flowers are rare in the wild but not impossible: when revisiting again population \#3334 of wild P. vulgaris in 


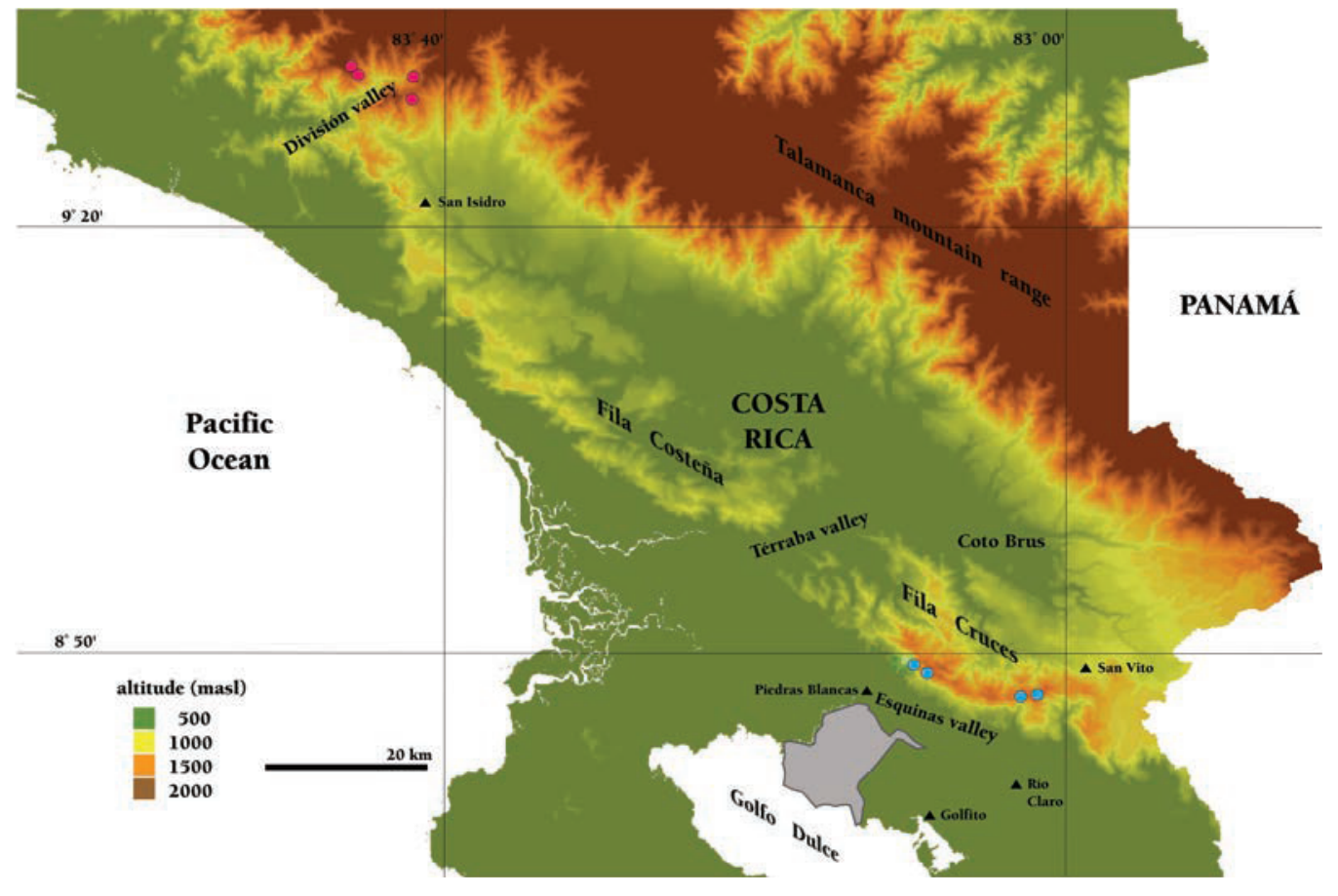

FIG. 7. Distribution map of the four populations of $P$. angucianae known to date in Fila Cruces in SE Costa Rica (blue dots), from W to E: Grayum et al. 10618, Debouck et al. 3243, Chaves \& Araya 0006, Debouck et al. 3369. The distribution of the four populations of P. hygrophilus known to date is shown north of San Isidro (red dots). The national park of Piedras Blancas is shown (light grey area, south of Piedras Blancas).

December 2017 in the province of San José, three individual plants had white corollas. The differences with $P$. hygrophilus (as described by Salcedo-Castaño et al. 2011) are plant size, leaflet shape, variegation of leaflets, size and vigor of inflorescence, size of primary and pedicelar bracts, lobes of calyx, width and color of standard, shape of developing pod, and seed shape (Table 4). The features reported in Tables 3 and 4 further suggest an affiliation with section Brevilegumeni. Finally, there is a geographical discontinuity between the ranges of both species with $P$. hygrophilus being distributed in the upper valley of División River at 1380-1640 masl (Fig. 7). The mountainous range "Fila Cruces," with Cerro Anguciana peaking at $1707 \mathrm{~m}$, is surrounded by lands below $1200 \mathrm{~m}$ (Fig. 7) - to the west the valley of Térraba River, to the north the vast hilly valley of Coto Brus, to the east a series of 1000-1200 m altitude ridges, and to the south the valley of Esquinas River-and largely developed on karstic substrate (Ulloa et al. 2011). This range is recognized as a separate botanical region distinct from the one of $P$. hygrophilus (Zamora et al. 2004a); this isolation is also recognized elsewhere (Holdridge et al. 1971). Not surprisingly, there are several endemic species in 'Fila Costeña Sur' (Zamora et al. 2004b; Huber et al. 2008), and this bean species would be another one. The altitude of P. angucianae seems to be $1400 \mathrm{~m}$ and higher, resulting in a small range just because of the topography.

One should note that the summit of the mountain is not far away, and if temperatures rise with ongoing deforestation (Fig. 2c), this could bring pressure on the population. Our third point relates to conservation status. According to IUCN categories (IUCN 2001), this new species could be considered both as "Data Deficient" and "Near Threatened." Along the former criterion, with only four populations known to date, an obvious priority is the definition of all populations of P. angucianae and their location using GPS technology. About the latter criterion, it should be noted that, in spite of lack of full data, several criteria of the "Vulnerable" category are already met, such as reduction in population size (affecting \#3243), geographic range less than 
$20,000 \mathrm{~km}^{2}$, fragmented area of occupancy, and population size estimated at less than 10,000 mature plants (each of the populations disclosed so far is of 40-60 fruiting plants). Master and co-workers (2000) defined a "G3 Vulnerable" rank for a rare species as 21 to 100 occurrences or 3,000 to 10,000 individuals. The northern slope of Cerro Anguciana (Fig. 2c) seems more deforested as compared to the southern slope (our observations in 2003-2017, Pérez-Rubio \& Mende 2018), possibly because of a lower steepness for logger trucks on the former. In view of this, the national park of Piedras Blancas created in September 1991 could be expanded to the northeast to include the southern slope of Cerro Anguciana. Reforestation with native species might be a better solution because of the topographic, edaphic and climatic conditions of that slope (Pérez-Rubio \& Mende 2018). It should be noted that "Fila Cruces," or any part of it, is not included currently in any protected area (Basco \& Kazmier 2015). On the other hand, if seeds are proven to be of orthodox behavior, P. angucianae could be backed up through conservation in seed banks (Maunder et al. 2004); a few seeds of population \#3369 have been collected for that purpose.

A final comment stresses once more the importance of making and keeping good, well documented voucher specimens as indicated elsewhere for the Guatemalan teosintes (Iltis et al. 1986). The voucher specimens left at INB and MO called our attention to a plant and place worth re-visiting in the field and good data left by Michael Grayum and his collecting team guided us to Cerro Anguciana. When we started assembling evidence about the presence of wild bean species in the rain forests of Costa Rica, the records were sparse and it would be impossible to predict where to find more populations representative of these different species by using Geographic Information System models (Jones et al. 1997; Ramírez-Villegas et al. 2010). Voucher specimens of populations visited early on were, and continue to be, of paramount importance in order to validate poorly known taxa.

\section{ACKNOWLEDGMENTS}

This work has been possible thanks to a grant provided by the Global Crop Diversity Trust (GCDT), the support of which is fully acknowledged, in the framework of the Project on Crop Wild Relatives and the Vicerrectoría de Investigación of the University of Costa Rica (UCR) project 736-B6-510: "Collection and conservation of wild bean, rice and potato relatives in Costa Rica." The authors thank the Ministerio de Ambiente y Energía (MINAE) of Costa Rica and express full appreciation to Ing. Javier Guevara Sequeira and Dr. Lourdes Vargas Fallas for their invaluable help for the research permits. They also want to acknowledge the support of the "Representación de la FAO en Costa Rica" through the Project "Semillas para el Desarrollo." The valuable help of Karolina Martínez Umaña and the contribution of MSc. Eddison José Araya Morales (Instituto Nacional de Innovación y Transferencia en Tecnología Agropecuaria) for the map has been much appreciated.

The authors thank Luigi Guarino (GCDT), Joe Tohme (CIAT), and Margoth Sequeira (UCR) for their continuing interest in this project. They also express deep appreciation to the Curators of the Herbaria: A, AGUAT, BM, BR, CAS, CHAPA, COL, CR, DS, DUKE, ENCB, F, G, GH, HNMN, IBUG, IEB, INB, ITIC, K, L, LAGU, LL, M, MEXU, MICH, MO, NA, NY, O, SI, RSA, TEX, UC, US, USJ, and WIS for keeping specimens of the section Brevilegumeni for study in situ by one of us (DGD). Special thanks are expressed to the editor of JBRIT, an anonymous reviewer, and Giles Waines for very pertinent comments to improve the manuscript. Last but not least, the authors desire to warmly thank Ramón Fallas Chinchilla, Alexander Fallas González, and Herman Picado Ramírez, all inhabitants of district of Chánguena, Buenos Aires, for valuable indications about the logging paths in order to get to Cerro Anguciana.

\section{REFERENCES}

Araya-Villalobos, R., W.G. González-Ugalde, F. Camacho-Chacón, P. Sánchez-Trejos, \& D.G. Debouck. 2001. Observations on the geographic distribution, ecology and conservation status of several Phaseolus bean species in Costa Rica. Genet. Resources \& Crop Evol. 48(3):221-232.

BAsco, G. \& R. Kazmier. 2015. National parks of Costa Rica. Cornell University Press, Ithaca, New York, U.S.A.

Bolaños-Montero, R.A. \& V. Watson-Céspedes. 1993. Mapa ecológico de Costa Rica. Centro Científico Tropical. Scale 1:200.000. San José, Costa Rica. 9 sheets. 
Debouck, D.G. 2017a. Cahiers de phaséologie: Sections Bracteati, Brevilegumeni, Falcati, Paniculati, Phaseoli, Xanthotricha and Phaseolus microcarpus. Centro Internacional de Agricultura Tropical, Cali, Colombia. https://ciat.cgiar.org/whatwe-do/crop-conservation-and-use (under "Publications: Program Files"). Accessed 22 Dec 2017.

Deвouck, D.G. 2017b. List of museums of natural history and herbaria studied, and dates of visit. International Center for Tropical Agriculture, Cali, Colombia. https://ciat.cgiar.org/what-we-do/crop-conservation-and-use (under "Publications: Program Files"). Accessed 22 Dec 2017.

Delgado-Salinas, A.O. 1985. Systematics of the genus Phaseolus (Leguminosae) in North and Central America. Ph.D. Thesis, University of Texas-Austin, Texas, U.S.A.

Delgado-Salinas, A.O. 2001. Phaseolus L. In: W.D. Stevens, C. Ulloa-Ulloa, A. Pool, \& O.M. Montiel, eds. Flora de Nicaragua - Angiospermas (Fabaceae - Oxalidaceae). Missouri Botanical Garden Press, St. Louis, Missouri, U.S.A. Pp. $1042-1046$.

Delgado-Salinas, A., M. Thulin, R. Pasquet, N. Weeden, \& M. Lavin. 2011. Vigna (Leguminosae) sensu lato: The names and identities of the American segregate genera. Amer. J. Bot. 98(10):1694-1715.

Freytag, G.F. \& D.G. Debouck. 2002. Taxonomy, distribution, and ecology of the genus Phaseolus (LeguminosaePapilionoideae) in North America, Mexico and Central America. Sida Bot. Misc. 23:1-300.

Gómez-Pignataro, L.D. 1986. Vegetación de Costa Rica. Apuntes para una biogeografía costarricense. Vol. 1. Editorial Universidad Estatal a Distancia, San José, Costa Rica.

Herrera-Soto, W. 1985. Clima de Costa Rica. Editorial Universidad Estatal a Distancia. San José, Costa Rica.

Herrera-Soto, W. \& L.D. Gómez-Pignataro. 1993. Mapa de Unidades Bióticas de Costa Rica. Escala 1:685,000. U.S. Fish and Wildlife Service, The Nature Conservancy and Fundación Gómez-Dueñas, San José, Costa Rica, C.A. 1 map.

Holdridge, L.R., W.C. Grenke, W.H. Hatheway, T. Liang, \& J.A. Tosi. 1971. Forest environments in tropical life zones: A pilot study. Pergamon Press, Oxford, U.K.

Huber, W., A. Weissenhofer, N. Zamora, \& A. Weber. 2008. Plant diversity and biogeography of the Golfo Dulce region, Costa Rica. In: A. Weissenhofer, W. Huber, V. Mayer, \& G. Aubrecht, eds. Natural and cultural history of the Golfo Dulce region, Costa Rica. Stapfia 88:97-103.

Ittis, H.C., D.A. Kolterman, \& B.F. Benz. 1986. Accurate documentation of germplasm: The lost Guatemalan teosintes (Zea, Gramineae). Econ. Bot. 40(1):69-77.

Instituto Meteorológico Nacional (IMN). 1985. Atlas climatológico de Costa Rica. Ministerio de Agricultura y Ganaderia. San José, Costa Rica.

Instituto Meteorológico Nacional (IMN). 2005. Precipitación promedio anual en Costa Rica. Ministerio del Ambiente, Energía y Telecomunicaciones. San José, Costa Rica. 1 map.

International Union for the Conservation of Nature (IUCN). 2001. The IUCN Red List of Threatened Species. Categories and criteria (version 3.1). www.iucnredlist.org/static/categories_criteria_3_1. Accessed 27 Mar 2018.

Jones, P.G., S.E. Beebe, J. Tohme, \& N.W. Galwey. 1997. The use of geographical information systems in biodiversity exploration and conservation. Biodivers. Conserv. 6:947-958.

LACKEY, J.A. 1983. A review of generic concepts in American Phaseolinae (Fabaceae, Faboideae). Iselya 2(2):21-64.

LACKEY, J.A. \&W.G. D'ARCY. 1980. Phaseolus. Family 83. Leguminosae. Flora of Panama. Ann. Missouri Bot. Gard. 67:746-751.

MaréChal, R., J. Mascherpa, \& F. Stainier. 1978. Etude taxonomique d'un groupe complexe d'espèces des genres Phaseolus et Vigna (Papilionaceae) sur la base de données morphologiques et polliniques, traitées par l'analyse informatique. Boissiera 28:1-273.

Master, L.L., B.A. Stein, L.S. Kutner, \& G.A. Hammerson. 2000. Vanishing assets: Conservation status of U.S. species. In: B.A. Stein, L.S. Kutner, \& J.S. Adams, eds. Precious heritage: The status of biodiversity in the United States. Oxford University Press, New York, New York, U.S.A. Pp. 93-118.

Maunder, M., K. Havens, E.O. Guerrant JR., \& D.A. Falk. 2004. Ex situ methods: A vital but underused set of conservation resources. In: E.O. Guerrant Jr., K. Havens, \& M. Maunder, eds. Ex situ plant conservation: Supporting species survival in the wild. Island Press, Washington D.C., U.S.A. Pp. 3-20.

McNeill, J., F.R. Barrie, W.R. Buck, V. Demoulin, W. Greuter, D.L. Hawksworth, P.S. Herendeen, S. Knapp, K. Marhold, J. Prado, W.F. Prud'homme Van Reine, G.F. Smith, J.H. Wiersema, \& N.J. Turland. 2012. International code of nomenclature for algae, fungi, and plants (Melbourne Code). International Association for Plant Taxonomy. Regnum Veg. 154. Koeltz Scientifc Books, Königstein, Germany.

Pérez-Rubio, I. \& A. Mende. 2018. Análisis espacial de susceptibilidad de erosión en una cuenca hidrográfica del trópico húmedo de Costa Rica. Rev. Cienc. Ambient. 52(1):1-26.

PIPER, C.V. 1926. Studies in American Phaseolinae. Contr. U.S. Natl. Herb. 22(9):663-701. 
Ramírez-Villegas, J., C. Khoury, A. Jarvis, D.G. Debouck, \& L. Guarino. 2010. A gap analysis methodology for collecting crop genepools: A case study with Phaseolus beans. PloS ONE 5(10):1-18.

Salcedo-Castaño, J., R. Araya-Villalobos, N. Castañeda-Alvarez, O. Toro-Chica, \& D.G. Debouck. 2011. Phaseolus hygrophilus (Leguminosae-Papilionoideae), a new wild bean species from the wet forests of Costa Rica, with notes about section Brevilegumeni. J. Bot. Res. Inst. Texas 5(1):53-65.

SAWYER, J.O. \& A.A. LYNDSEY. 1971. Vegetation of the life zones in Costa Rica. Indiana Acad. Sci., Monogr. 2:1-214.

SPENCER, R., R. CRoss, \& P. Lumley. 2007. Plant names: A guide to botanical nomenclature. $3^{\text {rd }}$ edition. CSIRO Publishing, Collingwood, Australia, and CABI, Wallingford, U.K.

THIERS, B.M. 2017. [continuously updated]. Index Herbariorum: A global directory of public herbaria and associated staff. New York Botanical Garden's Virtual Herbarium, New York, U.S.A. http://sweetgum.nybg.org/science/ih/. Accessed 8 Nov 2017.

Torres-González, A.M., O. Toro-Chica, \& D.G. Debouck. 2001. Phaseolus talamancensis, a new wild bean species (Leguminosae, Phaseolinae) from montane forests of eastern Costa Rica. Novon 11(2):280-286.

Tosi-Olın, J.A. 1969. Mapa ecológico, República de Costa Rica, según la clasificación de zonas de vida del mundo de L.R. Holdridge. Centro Científico Tropical, San José, Costa Rica. 1 sheet.

Tropicos.org. 2017. Missouri Botanical Garden, St. Louis, Missouri, U.S.A. www.tropicos.org/Specimen/899574. Accessed 22 Dec 2017.

Ulloa, A., T. Aguilar, C. Goicoechea, \& R. Ramírez. 2011. Descripción, clasificación y aspectos geológicos de las zonas kársticas de Costa Rica. Rev. Geol. Amer. Centr. 45:53-74.

Zamora, N. 2010. Fabaceae. In: B.E. Hammel, M.H. Grayum, C. Herrera, \& N. Zamora, eds. Manual de plantas de Costa Rica. Vol. 5. Dicotiledóneas (Clusiaceae-Gunneraceae). Missouri Botanical Garden Press, St. Louis, Missouri, U.S.A. Pp. 395-775.

Zamora, N., B.E. Hammel, \& M.H. Grayum. 2004a. Vegetation. In: B.E. Hammel, M.H. Grayum, C. Herrera, \& N. Zamora, eds. Manual de plantas de Costa Rica. Vol. 1. Introducción. Missouri Botanical Garden Press, St. Louis, Missouri, U.S.A. Pp. 91-216.

Zamora, N., B.E. Hammel, \& M.H. Grayum. 2004b. Novelties. In: B.E. Hammel, M.H. Grayum, C. Herrera, \& N. Zamora, eds. Manual de plantas de Costa Rica. Vol. 1. Introducción. Missouri Botanical Garden Press, St. Louis, Missouri, U.S.A. Pp. 217-240. 